(с) Шликова О. А., Ізмайлова О. В., Лисанець Ю. В.

УДК 612.438:616.61:611.018.1

DOI https://doi.org/10.31718/mep.2018.22.3-4.07

\title{
ПРИРОДНІ ПЕПТИДНІ КОМПЛЕКСИ ТИМУСА ТА НИРОК ПІДСИЛЮЮТЬ АПОПТОЗ ТРАНСФОРМОВАНИХ Т-КЛІТИН, АЛЕ НЕ ВПЛИВАЮТЬ НА ПРОЦЕСИ АПОПТОЗУ В-КЛІТИН*
}

\author{
Шликова О. А., Ізмайлова О. В., Лисанець Ю. В.
}

Українська медична стоматологічна академія, м. Полтава

Одним із найважливіших питань сучасної медицини є пошук методів регуляції програмованої загибелі клітин із метою розробки нових підходів до лікування, у тому числі раку та лейкемій. Гуморальна регуляція процесів апоптозу за допомогою цитокінів, гормонів, ростових факторів, пептидів посідає важливе місце серед механізмів регуляції апоптозу. Досліджено вплив природних пептидних комплексів тимусу та нирок на процеси апоптозу клітин НРВALL (гострий Т-клітинний лейкоз) та ВЈАВ (лімфома Беркіта). Показано, що природні пептидні комплекси тимуса та нирок мають незначний стимулюючий вплив на апоптоз пухлинних В-клітин лінії ВЈАВ у низьких концентраціях, а при збільшенні дози пептидів не впливають на процеси апоптозу; вірогідно підсилюють процеси елімінації трансформованих Т-клітин шляхом активації в них процесів апоптозу. При дії природного пептидного комплексу тимусу цей ефект має дозозалежний характер - зростає при збільшенні дози.

Ключові слова: апоптоз, природні пептидні комплекси тимуса та нирок, трансформовані Т- та В-клітини.

Апоптоз відіграє ключову роль у видаленні з організму небажаних або потенційно небезпечних клітин, наприклад, трансформованих клітин [1]. 3 літературних джерел відомо, що супресія апоптозу може бути однією з причин підсилення проліферативної активності передракових та ракових новоутворень [2].

Порушення плину апоптотичних процесів може призвести до порушення гомеостазу лімфопроліферативної системи та розвитку лейкемій та лімфом [3]. Експериментальне підтвердження отримали припущення про те, що в основі багатьох лімфопроліферативних захворювань лежить процес порушення клітинного апоптозу за типом блоку негативних наслідків активації, в результаті чого виникає нестримувана клітинна проліферація [4].

Дефекти апоптозу лежать в основі як пухлиноутворення, так і появи стійкості пухлин до лікарських препаратів [5,6]. Тому, одним із найважливіших питань $є$ пошук методів регуляції програмованої загибелі клітин з метою розробки нових підходів до лікування раку та лейкемій. Інгібуючі ефекти можуть бути націлені на різні рівні регуляції: перехват стимулу, формування антагонізму до індуктора, припинення трансляції сигналу, блокада клітинних каталітичних ферментів - учасників клітинного самогубства $[7,8]$.

Гуморальна регуляція процесів апоптозу за допомогою цитокінів, гормонів, ростових фракторів, пептидів посідає важливе місце серед механізмів регуляції апоптозу.

Вивченню механізмів впливу регуляторних пептидів на процеси апоптозу надається у теперішній час значна увага, так як накопичуються дані про підсилення або гальмування процесів апоптозу клітин різних тканин під дією пептидних речовин $[9,10]$.

Показано, що синтезовані проапоптотичні пептиди володіють антипухлинною активністю проти пухлин кровоносних судин у мишей. При проникненні в середину клітини вони пошкоджують мембрани мітохондрій, що викликає загибель ендотеліальних пухлинних клітин [11]. Отримані дані про наявність у пептидів, виділених із тимуса, антиканцерогенних властивостей [12].

Метою роботи було вивчення впливу природних пептидних комплексів тимусу та нирок на процеси апоптозу клітин HPB-ALL (гострий Т-клітинний лейкоз) та BJAB (лімфома Беркіта).

\section{Матеріали та методи дослідження}

Дослідження були проведені на клітинах лінії ВJАВ (лімфома Беркіта) та клітинах лінії HBP-ALL (гострий Т-клітинний лейкоз людини). Клітини культивували в середовищі RPMI-1640 (Gibco BRL) із додаванням $10 \%$ ембріональної телячої сироватки (BioMark), 10мM HEPES (SIGMA, USA) і 100 мкг/мл гентаміцину сульфату (ГНЦЛС, Україна). Природний пептидний комплекс тимусу (тималін) (Россия, Санкт-Петербург, ЗМП) і природний пептидний комплекс нирок (ППКН) [13] додавали до культурального середовища в концентрації 0,01 мкг/мл, 0,1 мкг/мл, 1 мкг/мл, 10 мкг/мл відповідно та інкубували 24 години при $37^{\circ} \mathrm{C}$ у вологому повітрі з $5 \% \mathrm{CO}_{2}$.

Досліджували морфологічні зміни при апоптозі: гіперхромність ядер, конденсацію й фрагментацію хроматину. Крім класичного забарвлення за МайГрюнвальдом-Романовським [14] використовували також фрлуоресцентний "ядерний" барвник Hoechst 33342 [15]. Розраховували кількість клітин із морфологічними ознаками апоптозу як відсоток клітин із наявністю фрагментації або конденсації хроматину на 100 лімсооцитів.

ДНК з трансформованих клітин, що досліджувались, виділяли за допомогою фенол-хлороформного методу. Проводили аналіз міжнуклеосомної фррагментації ДНК у вигляді “сходинок”, яка виникає послідовно при розщепленні ДНК ендонуклеазами, з використанням агарозного гель-електрофоорезу з візуалізацією результатів в ультрафіолетовому світлі в присут-

\footnotetext{
* Цитування при атестації кадрів: Шликова О. А., Ізмайлова О. В., Лисанець Ю. В. Природні пептидні комплекси тимуса та нирок підсилюють апоптоз трансформованих т-клітин, але не впливають на процеси апоптозу в-клітин.. // Проблеми екології і медицини. - 2018. - T. 22, № 3-4. - С. 25-29.
} 
ності етидіуму броміду [14]. В якості маркера молекулярної ваги використовували ДНК $\lambda$-фрага після обробки рестриктазою Pst 1. Результати документували фотографрічно.

Підраховували загальну кількість клітин в 1 мл суспензії. Проводили диференціювання живих та мертвих клітин за допомогою забарвлення клітин барвником акридиновий оранжевий/етідіум бромід для оцінки відсоткового вмісту клітин, що знаходяться в стані апоптозу [16].

Підраховували кількість зелених (живих) і оранжевих (мертвих) клітин за допомогою мікроскопу “Люмам-Р-8” (Ломо, Росія) при збільшенні х360 під фллуоресцентним мікроскопом в ультрафіолетовому світлі та видимій частині спектра. Розраховували кількість мертвих і живих клітин, як відсоток клітин із наявністю

оранжевого й зеленого забарвлення відповідно на 100 клітин.

\section{Результати та їх обговорення}

Дослідження загальної кількості клітин лінії ВЈАВ та їх життєздатності показали, що в вихідній культурі загальна кількість клітин складала 3,0 \pm 0,4 × 10\% відсоток мертвих клітин дорівнюв 4,6 $\pm 0,8$. Кількість клітин при дії тималіну в мінімальній дозі - 0,01 мкг/мл та в дозі 0,1 мкг/мл незначно підвищилась, в дозах 1 мкг/мл та 10 мкг/мл загальна кількість клітин дорівнювала контрольній групі. Відсоток мертвих клітин майже не змінювався при дії тималіну і ППКН у дозах 0,01 мкг/мл, 0,1 мкг/мл у порівнянні з контрольними клітинами, при збільшенні дози пептидів дорівнював контрольній групі (табл. 1).

Таблиия 1

Загальна кількість та життєздатність клітин ВЈАВ при дії тималіну та ППКН

\begin{tabular}{|c|c|c|c|c|c|c|c|c|c|}
\hline \multirow{2}{*}{ Показник } & \multirow{2}{*}{$\begin{array}{c}\text { Конт- } \\
\text { роль }\end{array}$} & \multicolumn{4}{|c|}{ Тималін, мкг/мл } & \multicolumn{4}{c|}{ ППКН, мкг/мл } \\
\cline { 3 - 10 } & 0,01 & 0,1 & 1 & 10 & 0,01 & 0,1 & 1 & 10 \\
\hline 1 & 2 & 3 & 4 & 5 & 6 & 7 & 8 & 9 & 10 \\
\hline $\begin{array}{c}\text { Число } \\
\text { клітин 10\%/мл, } \\
(\mathrm{n}=6)\end{array}$ & $3,0 \pm 0,4$ & $4,3 \pm 0,5$ & $4,5 \pm 0,4$ & $2,8 \pm 0,22$ & $3,4 \pm 0,3$ & $4,0 \pm 0,5$ & $3,8 \pm 0,6$ & $3,5 \pm 0,42$ & $3,0 \pm 0,5$ \\
\hline $\begin{array}{c}\text { Кількість } \\
\text { мертвих клітин,\% } \\
(\mathrm{n}=6)\end{array}$ & $4,6 \pm 0,8$ & $5,66 \pm 0,66$ & $5,2 \pm 0,9$ & $4,8 \pm 0,3$ & $4,16 \pm 0,7$ & $5,5 \pm 0,61$ & $5,8 \pm 0,7$ & $4,1 \pm 0,7$ & $4,16 \pm 0,74$ \\
\hline
\end{tabular}

Примітка: * $p<0,05-$ у порівнянні з контрольними клітинами;

При дослідженні морфологічних проявів апоптозу при забарвленні за Май-Грюнвальдом-Романовським та фарбування Hеochst 33342 при дії мінімальних доз тималіну та ППКН спостерігалось незначне підвищен-

ня кількості клітин із фррагментацією ядра. При збільшенні дози пептидів рівень клітин із наявністю фрагментації ядра дорівнював контрольній групі (табл. 2).

Таблиця 2 Морфологічні ознаки апоптозу при дії тималіну і ППКН

\begin{tabular}{|c|c|c|c|c|c|c|c|c|c|c|}
\hline \multirow{2}{*}{\multicolumn{2}{|c|}{ Показник }} & \multirow{2}{*}{$\begin{array}{l}\text { Конт- } \\
\text { роль }\end{array}$} & \multicolumn{4}{|c|}{ Тималін, мкг/мл } & \multicolumn{4}{|c|}{ ППКН, мкг/мл } \\
\hline & & & 0,01 & 0,1 & 1 & 10 & 0,01 & 0,1 & 1 & 10 \\
\hline \multirow{2}{*}{$\begin{array}{c}\text { Май- } \\
\text { Грюн- } \\
\text { вальд- } \\
\text { Рома- } \\
\text { новсь- } \\
\text { кий }\end{array}$} & $\begin{array}{c}\text { Фрагмента- } \\
\text { ція, } \% \\
\text { n=6 }\end{array}$ & $1,0 \pm 0,5$ & $1,8 \pm 0,6$ & $1,50 \pm 0,22$ & $1,16 \pm 0,16$ & $1,33 \pm 0,2$ & $1,6 \pm 0,3$ & $1,25 \pm 0,17$ & $1,16 \pm 0,4$ & $0,5 \pm 0,36$ \\
\hline & $\begin{array}{c}\text { Конденса- } \\
\text { ція, \% } \\
\text { n=6 }\end{array}$ & $3,5 \pm 0,42$ & $4,5 \pm 0,5$ & $3,3 \pm 0,49$ & $3,0 \pm 0,57$ & $3,0 \pm 0,51$ & $4,3 \pm 0,61$ & $3,0 \pm 0,63$ & $4,0 \pm 0,44$ & $3,2 \pm 0,47$ \\
\hline \multirow{2}{*}{ 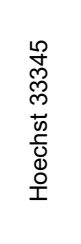 } & $\begin{array}{c}\text { Фрагмента- } \\
\text { ція,\% } \\
\text { n=6 }\end{array}$ & $1,5 \pm 0,5$ & $2,3 \pm 0,7$ & $2,0 \pm 0,36$ & $1,66 \pm 0,33$ & $1,33 \pm 0,33$ & $2,5 \pm 0,42$ & $1,0 \pm 0,34$ & $1,45 \pm 0,18$ & $1,58 \pm 0,18$ \\
\hline & $\begin{array}{c}\text { Конденса } \\
\text { ція, \% } \\
\text { n=6 }\end{array}$ & $4,5 \pm 0,7$ & $5,7 \pm 0,6$ & $4,66 \pm 0,33$ & $5,16 \pm 0,54$ & $4,3 \pm 0,55$ & $5,66 \pm 0,76$ & $4,5 \pm 0,42$ & $5,0 \pm 0,25$ & $5,16 \pm 0,6$ \\
\hline
\end{tabular}

Примітка: *- $0<0,05$ у порівнянні з контрольними клітинами;

Подібні зміни спостерігались і при виявленні конденсації хроматину. Результати досліджень електрофоретичних зразків ДНК клітин при дії тималіну і ППКН показали, що істотних змін не відбулося, міжнуклеосомальна деградація ДНК не спостерігалась (рис.1).

Таким чином, природні пептидні комплекси тимуса та нирок мають незначний стимулюючий вплив на апоптоз пухлинних В - клітин лінії ВЈАВ у низьких концентраціях, а при збільшенні дози пептидів не впливають на процеси апоптозу. Відомо, що окремі лінії В - клітин мають великий рівень експресії Bcl-2, що обумовлює їх високу стійкість до дії апоптоз-індукуючих чинників [17]. 


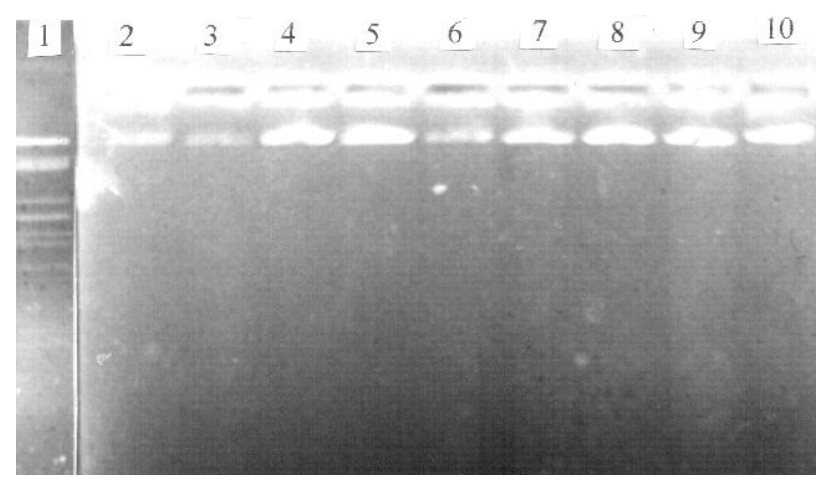

Рисунок 1. Аналіз міжнуклеосомальної деградації ДНК клітин лінії ВЈAB людини при дії різних доз тималіну і ППКН при електрофорезі в агарозному гелі. 1- маркер молекулярної ваги ДНК лямбда-фрага. 2- ДНК клітин лінії ВЈАВ людини (контроль);

3- клітини, що підлягали впливу тималіну (0,01 мка/мл);

4- клітини, що підлягали впливу тималіну (0,1 мка/мл),

5- клітини, що підлягали впливу тималіну (1 мка/мл);

6 - клітини, що підлягали впливу тималіну (10 мка/мл);

7- клітини, що підлягали впливу ППКН (0,01 мка/мл);

8 - клітини, що підлягали впливу ППКН (0,1 мка/мл);

9 - клітини, що підлягали впливу ППКН (1 мка/мл);

10 - клітини, що підлягали впливу ППКН (10 мка/мл).

Дослідження загальної кількості клітин лінії НВРALL та їх життєздатності показали, що кількість клітин при дії мінімальної дози (0,01 кг/мл) тималіну та ППКН підвищилась (рис.2), в дозах 0,1 мкг/мл і 1 мкг/мл також була вища в порівнянні з кількістю контрольних клітин, що дорівнювала $3,5 \pm 0,24 \times 10^{6} /$ мл $(p<0,05)$, але спостерігалась тенденція до зменшення кількості клітин у порівнянні з мінімальною дозою.

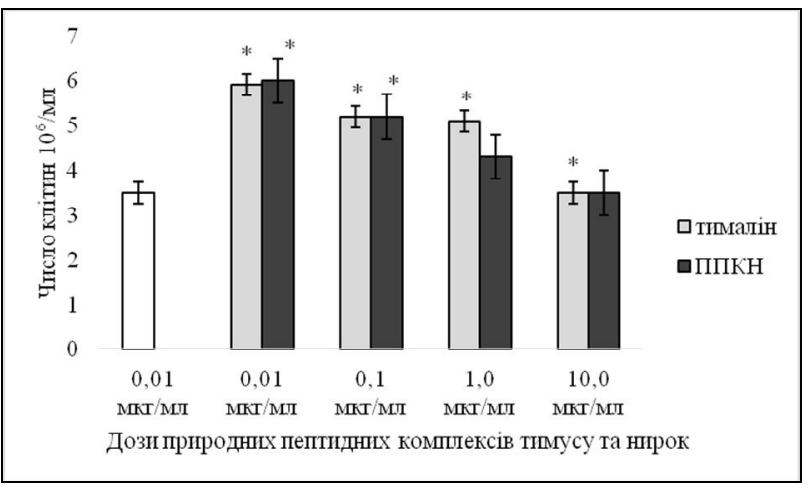

Рисунок 2. Загальна кількість клітин HBP-LLA при дії природних пептидних комплексів тимусу (тималін) та нирок (ППКН)

* $p<0,05-$ у порівнянні з контрольними клітинами.

У максимальній дозі пептидів (10 мкг/мл) загальна кількість клітин дорівнювала контрольній групі. Відсоток мертвих клітин вірогідно підвищувався при дії тималіну і ППКН у дозах 0,01 мкг/мл, 0,1 мкг/мл у порівнянні з контрольними клітинами серед яких він дорівнював 5,8 $\pm 0,7$ ( $p<0,05)$, разом із цим при збільшенні дози пептидів відсоток мертвих клітин мав тенденцію до зниження (рис. 3).

При дослідженні морфологічних проявів апоптозу при забарвленні за Май-ГрюнвальдомРомановським при дії пептидних комплексів, що вивчалися, спостерігали типові апоптотичні ознаки із фрагментацією і пікнозом ядер, зменшення обсягу й розміру цитоплазми.

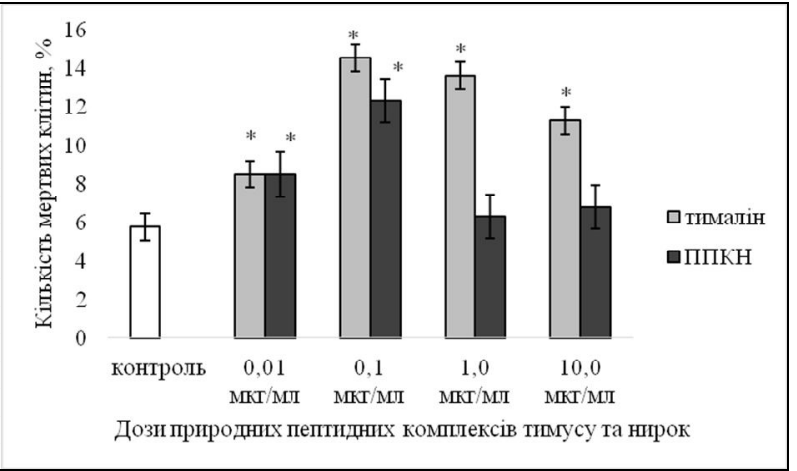

Рисунок 3. Життездатність клітин HBP-LLA при дії природних пептидних комплексів тимусу (тималін) та нирок (ППКН).

p<0,05- у порівнянні з контрольними клітинами.

Фарбування Heochst 33342, після обробки тималіном і ППКН, виявило фрлуоресцентні скупчення, характерні для ядерної ДНК - фррагментації й конденсації хроматину в клітинах. В контрольних клітинах відсоток клітин з фрагментацією та конденсацією при забарвленні за Май-Грюнвальдом-Романовським та Heochst 33342 складав $1,2 \pm 0,2$ та 1,6 $\pm 0,33$, відповідно. Було виявлено вірогідне підвищення відсотка клітин із наявністю фррагментації ядра, причому при дії тималіну цей ефект мав дозозалежний характер $(p<0,05)$ (рис. 4 a, б).
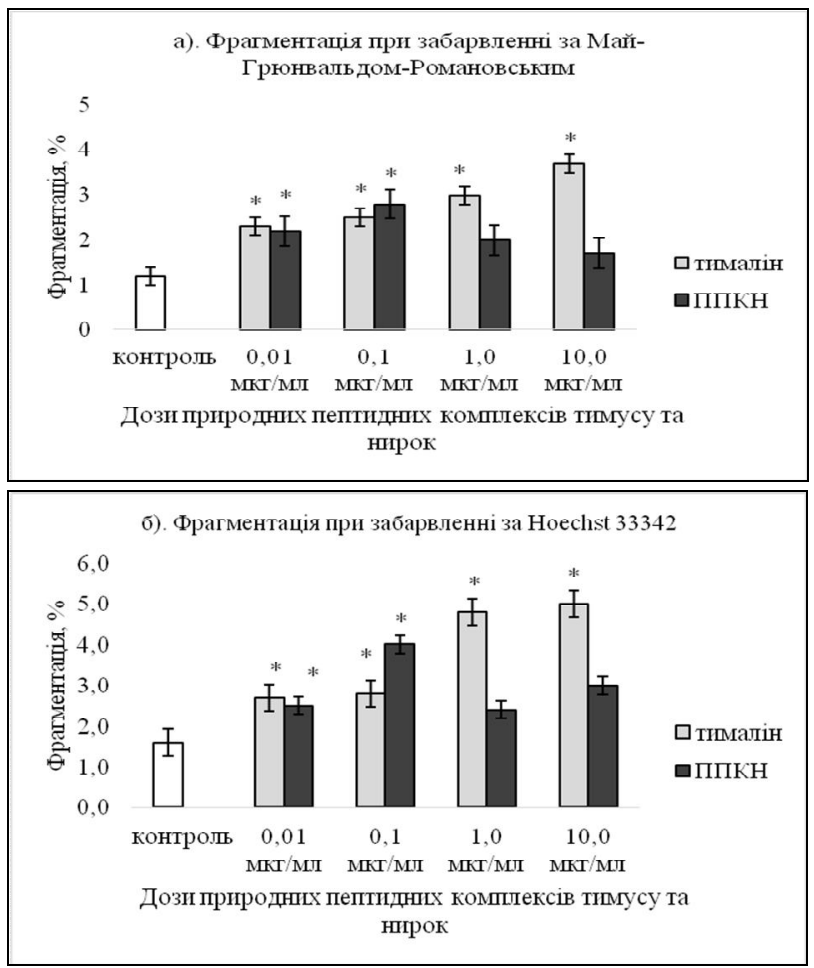

Рисунок 4 а,б. Морфологічні ознаки апоптозу

за забарвленням по Май-Грюнвальд-Романовському при дії природних пептидних комплексів тимусу (тималін) та нирок (ППКН).

* $p<0,05-$ у порівнянні з контрольними клітинами.

Подібні зміни спостерігались і при виявленні конденсації хроматину, але цей ефект був більш виражений при дії тималіну, ніж у ППКН. В контрольних клітинах конденсація хроматину була виявлена за забарвленням за Май-Грюнвальдом-Романовським та Heochst 33342 у 3,5 \pm 0,34 та 4,0 $\pm 1,0$ відсотках клітин, відповідно. Збільшення дози тималіну призводи- 
ло до підвищення кількості клітин, що підлягали апоптозу. При дії ППКН ми спостерігали різнонаправлену фазову дію: малі дози пептиду стимулювали апоптоз, а великі - пригнічували (рис. 5 а, б). Дія пептидів в малих дозах відбувається за рахунок генералізації сигнала шляхом утворення вторинних месенджерів, а при збільшенні дози спостерігається гіперактивація систем, що може призводити до пригнічення ефекту [18].
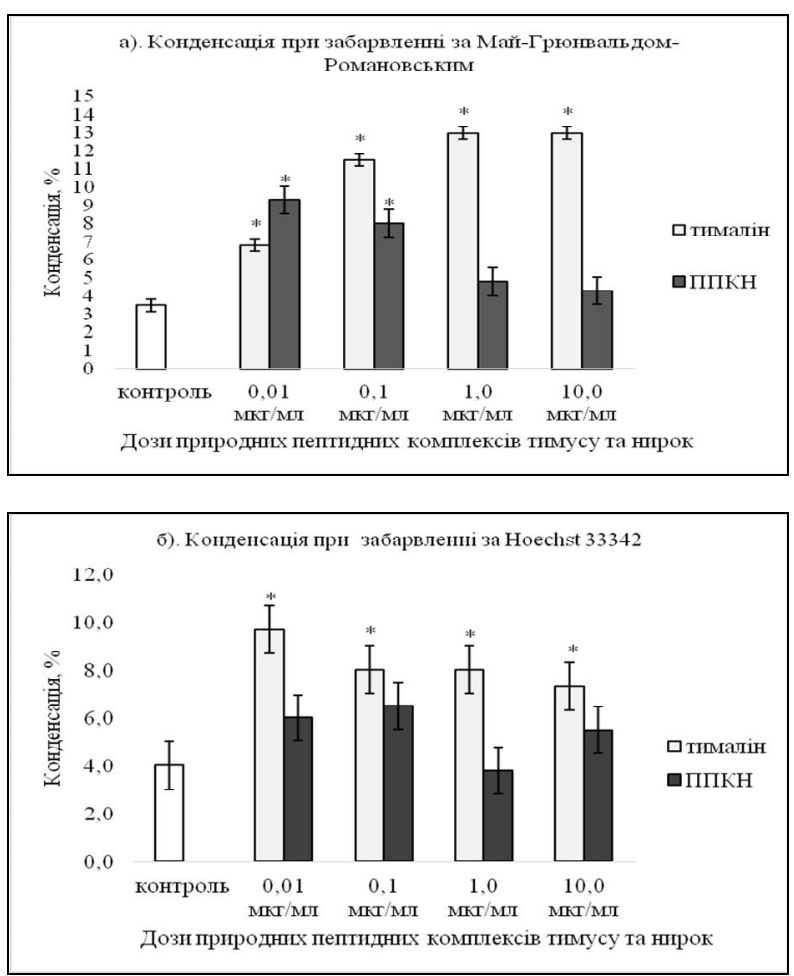

Рисунок 5 а,б. Морфологічні ознаки апоптозу за забарвленням по Hoechst 33345 при дії природних пептидних комплексів тимусу (тималін) та нирок (ППКН).

* $p<0,05-$ у порівнянні з контрольними клітинами.

Результати досліджень електрофоретичних зразків ДНК клітин при дії тималіну і ППКН показали, що істотних змін не відбулося, міжнуклеосомна деградація ДНК не спостерігалась (рис.6).

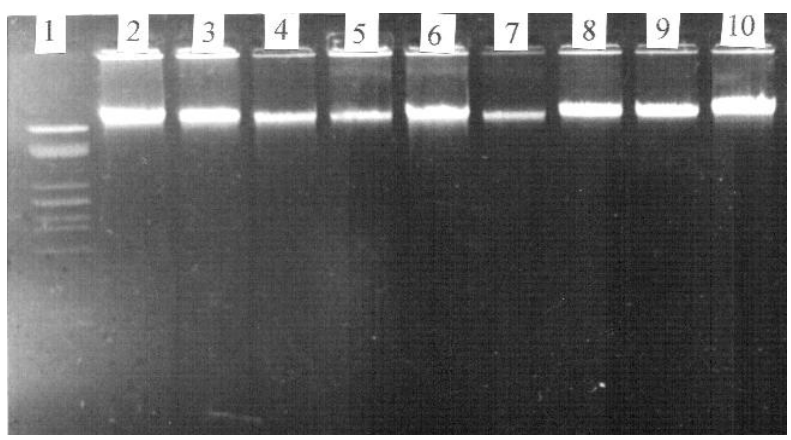

Pис.6. Аналіз міжнуклеосомальної деградації ДНК клітин лінії HPB-ALL при дії різних доз тималіну і ППКН при електрофорезі в агарозному гелі.

1-маркер молекулярної ваги: ДНК лямбда-фрага розрізана рестриктазою pst 1 ;

2 - ДНК клітин лінії НPB-ALL людини (контроль);

3 - клітини, що підлягали впливу тималіну (0,01 мке/мл);

4 - клітини, що підлягали впливу тималіну (0,1 мке/мл);

5 - клітини, що підлягали впливу тималіну (1 мка/мл);

6 - клітини, що підлягали впливу тималіну (10 мке/мл)

7 - клітини, що підлягали впливу ППКН (0,01 мкг/мл);

8 - клітини, що підлягали впливу тималіну ППКН (0,1 мкг/мл); 9 - клітини, що підлягали впливу ППКН (1 мке/мл);

10 - клітини, що підлягали впливу ППКН (10 мке/мл).
Таким чином, природні пептидні комплекси тимуса та нирок здатні підсилювати процеси апоптозу в трансорормованих Т-клітинах. При дії природного пептидного комплексу тимусу цей ефрект має дозозалежний характер.

Отже, природні пептидні комплекси тимусу та нирок вірогідно підсилюють процеси елімінації трансформованих Т-клітин шляхом активації в них процесів апоптозу, але не впливають на процеси апоптозу трансформованих В - клітин. Одним із механізмів дії пептидів може бути їх здатні зв'язуватися з молекулами ГКГС-І класу, що можуть брати участь в реалізації їх дії [19].

Отримані дані підтверджують висновок, що найбільшу активність пептидні біорегулятори виявляють по відношенню до тропного для них виду клітин і тканин. Можливо, на поверхні клітин існують специфічні сайти, що диференційовано сприймають вплив тимічних пептидів на програму апоптозу [20]. Одним із механізмів дії пептидів може бути їх здатні зв'язуватися 3 молекулами ГКГС-І класу, що можуть брати участь в реалізації їх дії.

\section{Література}

1. VDAC2 enables BAX to mediate apoptosis and limit tumor development / H.S. Chin, M.X. Li, I.K.L. Tan [et al.] // Nat. Commun. - 2018. - Vol. 9 (1). - P. 4976.

2. Kaser H.E. The role of apoptosis in normal ontogenesis and solid human neoplasms / H.E. Kaser, B. Bodey // In. Viv. - 2000. - Vol. 14, N. 6. - P. 789-803.

3. Reed J.C. Apoptosis-based therapies for hematologic malignancies / J.C. Reed, M. Pellecchia // Blood. - 2005. - Vol. 106. - P. 408-418.

4. Чередеев А.Н. Апоптоз как важный этап оценки иммунной системы по патогенетическому принципу / А.Н. Чередеев, Л.В. Ковальчук // Клиническая лабораторная диагностика. - 1997. - № 7. - С. 31-34.

5. Johnstone R.W. Apoptosis: A Link between Cancer Genetics and Chemotherapy / R.W. Johnstone, A. A. Ruefli, S.W. Lowe // Cell. - 2002. - Vol. 108. - P. 153-164.

6. PIM1 overexpression in T-cell lymphomas protects tumor cells from apoptosis and confers doxorubicin resistance by upregulating c-myc expression / X. Xiang, Di Yuan, Yao Liu [et al.] // Acta Biochim. Biophys. Sin. - 2018. - P. 1-7.

7. Methotrexate induces high level of apoptosis in canine lymphoma/leukemia cell lines / A. Pawlak, J. Kutkowska, B. Obminska-Mrukowicz [et al.] // Res. Vet. Sci. - 2017. Vol. 114. - P. 518-523.

8. ONC201 selectively induces apoptosis in cutaneous T-cell lymphoma cells via activating pro-apoptotic integrated stress response and inactivating JAK/STAT and NFkappaB pathways / X. Ni, X. Zhang, C.H. Hu [et al.] // Oncotarget. - 2017. - Vol. 8. - P. 61761-61776.

9. Трипептид неоген усиливает апоптоз Т-лимфоцитов человека при их ответе на митоген / М.Ф. Никонова, Т.Ю. Григорьева, М.М. Литвина [и др.] // Иммунология. - 2000. - № 4. - C. 35-37.

10. Dracorhodin perchlorate induces apoptosis in primary fibroblasts from human skin hypertrophic scars via participation of caspase 3 / P. Zhang, J. Li, X. Tang [et al.] // Eur. J. Pharmacol. - 2014. - Vol. 728. - P. 82-92.

11. Anti-cancer activity of targeted pro-apoptotic peptides / H.M. Ellerby, W. Arap, L.M. Ellerby [et al.] // Nat. Med. 1999. - Vol. 5, N. 9. - P. 1032-1038.

12. Зинченко С.В. Иммуномодуляторы в комплексной терапии онкологических больных (обзор литературы) / С.В. Зинченко // Поволжский онкологический вестник. 2014. - № 1. - C. 57-64.

13. Патент 10180 Україна, МПК А61 К37/00. Спосіб одержання біологічно активної речовини, що має регенераторну та модулюючу дію / Кайдашев І.П., Катрушов О.В.; заявник і патентовласник ТОВ «Фармапол». - № 94052069 ; заявл. 30.05.1994 ; опубл. 15.05.2001, Бюл. 4. 
14. Методи клінічних та експериментальних досліджень в медицині / [Л.В. Беркало, О.В. Бобович, Н.О. Боброва та ін.]; під ред. І.П. Кайдашева - Полтава: Полімет, 2003. -320 c.

15. Особенности индукции апоптоза этопозидом в различных злокачественных лимфоидных клеточных линиях человека / З.А. Бутенко, М.П. Завелевич, И.А. Смирнова [и др.] // Экспериментальная онкология. - 2000. - Т. 22, № 1-2. - C. 26-31.

16. Traganos F. Lysosomal proton pump activity: Supravital cell staining with acridine orange differential leukocytes subpopulations / F. Traganos, Z. Darzynkiewicz // Meth. Cell Biol. - 1994. - N. 41. - P. 185-195.

17. Protein Tyrosine Kinases p53/56 $6^{\text {lyn }}$ i p $72^{\text {syk }}$ in $\mathrm{MHC}$ class I-Mediated signal Transduction in B-Lymphoma Cells / A.E. Pedersen, S. Bregenholt, S. Skov [et al.] //
Experimental Cell Research - 1998 - Vol. 240 - P. 144 150.

18. Кузник Б.И. Имунофран - синтетический пептидный препарат нового поколения: иммунологические и патогенетические аспекты клинического применения / Б.И. Кузник, В.В. Лебедев // Иммунология. - 1999. - № 1. C. 25-30.

19. Кайдашев И.П. Роль молекул МНС I класса на опухолевых Т-клетках в передаче пептидного сигнала / И.П. Кайдашев, О.А. Ножинова // Імунологія та алергологія. - 2002. - № 2. - C. 22-25.

20. Samara P. Prothymosin Alpha and Immune Responses: Are We Close to Potential Clinical Applications? / P. Samara, K. Ioannou, O.E. Tsitsilonis // Vitam. Horm. 2016. - Vol. 102. - P. 179-207. 